\title{
The Effects of the Resource Curse Indices and Good Governance on Health Expenditures in Different Income Deciles
}

\author{
Abbas Assari \\ Tarbiat Modarres University, faculty member
}

Bahram Sahabi

Tarbiat Modarres University, faculty member

\section{Amir Hossein Mozayyeni}

Tarbiat Modarres University, faculty member

\author{
Ahmad Rasouli \\ PhD student in economics at the University of Tarbiat Modarres (Corresponding Author)
}

Doi:10.5901/mjss.2016.v7n4s2p203

\begin{abstract}
The views on health have gained a broader perspective today, so that according to these views, in addition to economic factors, non-economic factors (political, cultural and social ones) also affect health expenditures. Therefore, in this study the effect of 9 economic and non-economic indicators (indicators of good governance and resources curse) on the level of health expenditures in different income classes was studied using the XLSTAT software. The results of this study revealed that, indicators of inflation and employment (economic factors) most accounted for variations of health expenditures in different income classes. Also, it was revealed that economic and non- economic factors in higher and lower income deciles increased healthcare spending and in the middle deciles it had a negative impact on this expenditure; however, according to the authors, the positive nature of effect of factors on upon low and high deciles is different. From the view of researchers, in the lower deciles increased spending was generally due health problems (essential goods), but in higher income deciles increase in expenses was generally due to increased spending on health and beauty (luxury). According to the results, it was observed that variables of employment, economic growth and political stability in different income classes had a negative impact on health expenditures and other indicators had positive impact on health spending in income deciles. In other words, based on the results, real variables (growth and employment) had more effect than monetary variables (inflation) and non-economic variables (indicators of good governance and resource curse) on reducing health care costs among different income classes.
\end{abstract}

Keywords: healthcare, resource curse, good governance, PLS

\section{Introduction}

Until the late 1980s, the common understanding about the relationship between natural resource abundance and economic development was that the abundance of natural resources was an advantage for development. Since the late 1980s, many studies challenged this traditional understanding. These studies have shown that the abundance of natural resources (or at least certain types of natural resources) increased the possibility that countries experience negative economic, political and social effects such as poor economic performance, low levels of democracy, civil war and the government's dependency on a particular source in order to meet its expenses and lack of consistent tax systems. The literature is broadly accepted and the idea that natural resources are not advantageous for development is now accepted by scholars (Bannon ‘l. and Collier ‘P. 2003).

The growing costs of health systems around the world has become a main concern for health system managers and decision makers. Continued expansion of new and expensive health technologies, rising expectations of health systems and increased hard to treat and chronic diseases among the people are the important reasons for such growth. Increasing health care costs could be due to changes in economic and non-economic factors. For example, several 
studies have shown the relationship between different factors such as age, education, income level and even the city's location etc. and health level; however, given the special conditions of Iran (poor management at the macro level and the dependence of economic growth on oil revenues), it was tried to incorporate the effect of good governance and resource curse as health indicators alongside economic indicators to health function; so health can be a function of economic and noneconomic factors. Accordingly, health function can be developed as follows.

\subsection{Economic factors:}

1. Economic factors (economic growth, inflation, the Gini coefficient, employment) Non-economic factors:

2. The factors of good governance (corruption control, political stability, government effectiveness, regulatory quality)

3. Resource curse factors (the share of natural resource exports to GDP, the share of oil revenues from the budget, the institutional quality).

According to the above explanation, the purpose of this study was that by the incorporation of various factors in the health function, a realistic explanation of the factors affecting health in different income classes is obtained. To accommodate the special circumstances of health in oil-producing countries, in addition to economic indicators considered by Grossman, good governance indices and resource curse indices were also considered in this model so that these indices could provide a more realistic explanation of the health status of these countries. This paper is organized in five sections, following the introduction, the second part covers the literature including theoretical foundations, the third part contains background of the research. The fourth section provides calculation results and estimates of the partial least-squares models and finally the fifth part is dedicated to the conclusions and summing up the estimates.

\section{Theoretical Framework}

In the following, the affects on the health level of indices of the resource curse and good governance will be examined theoretically. Early studies attributed slight growth in resource-rich countries to "Dutch Disease", which designation dates back to recession in the Netherlands after the discovery of natural gas goes beaches (Gylfason 'Thorvaldur., 2001). Economy that is heavily resource-based is faced with two problems:

First, the share of exports in GDP growth is reduced, which impairs overall GDP growth.

Secondly, income is becoming increasingly dependent on the world price of its resources. This problem is often exacerbated by natural fluctuation of commodity prices.

Further studies stressed the role of government in overcoming the resource curse. The argument of governance essentially states that natural resource wealth causes large responsibility for state institutions denominated and therefore the country's institutions will be enabled to progress. There is a view that abundance of natural resources should have a positive effect on economic growth because economies with rich resources are more easily able to accumulate infrastructure and human capital (Sachs J Warner A., 1999: Murphy et al, 2000).

From the perspective of political economy, the wealth of natural resources give rise to conflict between stakeholders such as politicians, local tribes and citizens. Stakeholders are motivated to seek unfair rents of natural resources. In such cases, the governance, the relationship between resources and economic prosperity becomes a very key role. Abundance of resources is an advantage for any economy where government manage sources in order to maximize long-term revenue planning efficiently.

Conversely, if income distribution is uneven, it tend to over-extract remaining resources and abundance may not lead to economic growth. Leamer et al (1999) shows that in Latin America uneven distribution of income sources has led to income inequality, which resulted in failure to accumulate the necessary capital, including human capital and thus the ruin of sustained economic growth.

Generally, the natural resource sector is very capital intensive. So some positive consequences in the forward and backward industries are created with natural resource extraction industries and therefore learning by doing effect will not be expected to in this area. For this reason, allocating too much capital to natural resource sector results in high unemployment and less investment in education and health (Sachs and Warner, 1995). Generally, the natural resource sector is very capital intensive. So some positive consequences in the forward and backward linkages with natural resource extraction industries are created and therefore not expected to impact learning by doing in this area. For this 
reason, allocating too much capital to high unemployment in the natural resource sector wide, is less investment in education and health (Sachs and Warner, 1995).

Theoretically, the rich abundance of natural resources can promote the growth because rich resources can be used to create "big push" through more investment in economic infrastructure and development of human capital (Sachs and Warner, 1999: Murphy et al., 2000). Above studies attribute resource curse to the lack of good governance. Therefore, research on the extent to which resource curse goes back to lack of good governance, and to what extent this factor is effective in reducing the level of health indicators have not been considered. The Iranian economy is heavily dependent on oil, so if oil rents enters the economy within the institutional structural framework through the channel of the state budget, what happens to the economy? Relative changes between tradable and non-tradable sector in the productive sector of the economy after introducing and increasing oil rents and its distribution through the channel of government spending in the economy are shown in Figure 1.

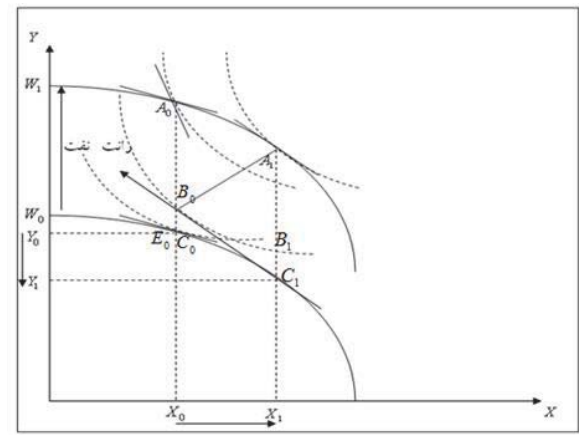

Source: Rasouli, 2015

Figure 1: Entry of oil rents to oil exporting countries with institutional-structural framework and reduced the level of health

The economy is first in equilibrium at $E_{0}$ where $Y_{0}$ is the value of tradable goods at international level and $X_{0}$ of nontradable goods is produced and relative prices is $P_{0}$. Given that the ratio of consumption of tradable goods to that of the non-traded goods is $A_{0} B_{0} / C_{0} B_{0}$, with introduction of oil rent or increase of it by $W_{0} W_{1}$, total demand through state budget increases, as a result of which in initial allocation for domestic economic production and with respect to export, there is an inequilibrium between production and consumption and relative price of non-tradable goods increase. Given that after introduction and increase of oil rents, the government puts more emphasis on investment in non-tradable goods sector, the public investments in this sector (particularly infrastructure) increasingly increases demand in this sector, which results in influx of investment resources to it. As a result, with an increase in the relative price of non-traded goods, profitability in this sector increases and production sources shift from the tradable goods sector to the non-traded goods more than when private sector spends foreign exchange earnings.

Finally, the non-tradable sector of the economy reaches re-balance at $E_{1}$, where production of tradable goods reduces to $Y_{1}$ and production of non-tradable goods increases to $X_{1}$; the government demand for tradable goods and nontraded goods will be for the Add the effective state demand for tradable goods is $A_{1} B_{1}$ and for non-tradable goods, it is $C_{1} B_{1}$, and effective surplus demand for tradable goods is secured through import. Based on the discussions in this section, it is revealed that institutional-structural framework of an oil state determines the amount and manner of entering of oil rents from oil resources to to the economic subsystem, changes between productive and unproductive changes betweand finally departments and economic growth of the country. As a result, with the expansion of the non-productive sector and increasing corruption, the factors affecting health and its components are weakened. The community health level is accordingly weakened due to increased income inequality, reduced economic growth and expansion of nonproductive part that generally leads to rising inflation and declining purchasing power. As empirical evidence in Figure 2, the relationship between resource abundance and health expenditures for 196 countries is shown. According to Figure 2, a negative relationship exists between public health spending and the share of natural resources in the country. 


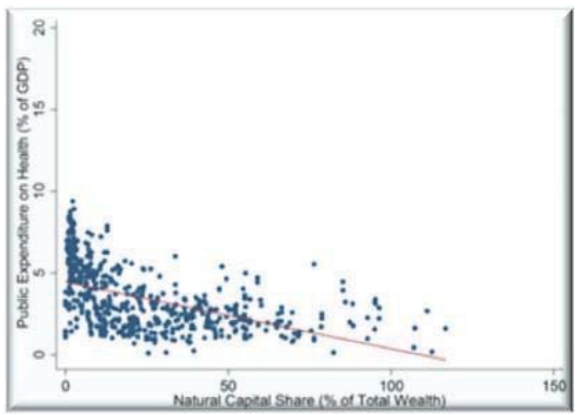

Source: Daniele, V. 2011

Figure 3: Relationship between public health spending and the share of natural resources

\section{Literature}

\subsection{Domestic Literature}

Asari Arani, Rasouli (2015) studied in an article entitled "Study of socio-economic, political and cultural factors on health in different income classes (using PLS)" the effect of 30 economic, social, cultural and political indices on the level of health in different income classes using the software XLSTAT. The results of this study revealed that economic factors affected the health of lower income deciles more than other factors so that with increase of income towards the higher deciles, the intensity of these factors reduced and effect of social and cultural factors increased. It should be noted that political factors including variable of sanctions had a significant negative effect on health level index, so that such effect is strong in lower deciles It should be noted that based on the results, variable of resource curse affected health index more than variable of good governance among different income classes. It is to be mentioned that this article is consistent with the said paper.

Sabbagh Kermani and Baskha (2008) in an article entitled "The role of good governance in improving the functioning of government spending: a case study of the health and education sectors in Muslim countries", using the modern concept of good governance, the role of this variable in performance improvement of education and health costs of selected countries of the OIC was studied. In other words, relations between the three areas of "good governance", "government spending" and "indicators of health and education" were studied. For this purpose, the indices of "corruption" and "administrative bureaucracy" were used as variables indicative of "governance" in these countries. The results indicate that increasing government expenditures on education and health is not always effective, but in countries where the conditions were better in terms of governance, such increased cost had a greater impact on health and education indicators. In other words, improvement of the governance improved efficiency of these two categories of spending.

\subsection{Foreign Literature}

Amini (2015) in a paper empirically investigates whether economic dependence on natural resources is related with less investment in health. After controlling for geographical and historical effects of the country, corruption, authoritarian regimes, income level and health status using panel data for 118 countries for the period of 1990-2008 didn't find compelling evidence in support of such negative effect.

Cockx (2014) for the first time conducted an empirical study of the relationship between the proceeds of natural resource wealth and public health. According to this author, he availability of wealth resources as a source of income inadvertently results in for the state's increased autonomy, which helps in reducing the level of government accountability to the people, which would reduce the government's interest in the health sector. Using panel data from many countries over the period 1991-2010 concluded that a significant inverse relationship existed between natural resource dependence (even abundance of resources) and public health spending over time.

Gylfason (2009) used panel data to draw the conclusion that school enrollment had an inverse relationship with abundance of resources, showing that this would reduce the level of human capital. He also concluded that on average 
public spending on education and health care in countries rich in minerals was significantly lower than the non-rich countries.

Davis (2013 ) made a comparison between countries rich and non-rich in terms of natural resources and thus concluded that investment in human capital in rich countries was significantly different from non-rich ones. He also concluded that resource-rich countries attached less importance to social and health indicators than non-rich ones.

Mehlum et al $(2002 ; 2006)$ argue that the impact of resource wealth on growth depends on the quality of institutions in each country so that lower the quality of the institution in the country the less the effect of resource abundance on health level in that country.

Deininger and Empuga (2004) conducted a study for the IMF, in which studied the effect of accountability of the executive bodies on increasing efficiency of the government expenditures. They evaluated the data for Uganda, and concluded that corruption and lack of accountability of executive institutions were the most important factors that reduced the quality of services provided by the government. The researchers pointed out that the accountability of various government institutions and bodies reduces the level of corruption in this system, and that one way to increase the performance of government spending is to increase accountability of the above-mentioned organs.

Kaufman et al. (2004) studied fit of various variables of governance to the health status of 177 countries. They considered variables of transparency and accountability and laws and rule of law. The results of their study showed that improvements in these variables had a negative relationship with infant mortality.

Virmani et al. (2006) conducted a study in which based on the quality of services provided by the state in South Asian countries, an estimate of the parameter of good governance for these countries was provided. Studying the effect of various economic and non-economic factors on this index, they stated that indices used as variables of good governance have a positive and significant effect on the quality of services provided by the government (such as roads, education and healthcare) and per capita incomes, thus improving the quality of governance will help the country in economic development.

Lazarova and Mosca (2007) used variables defined by Kaufman et al. (2007) for good governance to study the role of these variables on health status. The results of this study emphasize on the fact that good governance has a close relationship with life expectancy, but the problem with this study is that only the quantitative variables were used to express the health status while good governance often explains qualitative differences of the health status among different countries.

Filmer et al. (2000) used cross-sectional data to estimate the effect of health and non-health costs (economic, educational and cultural) of the government on their social outcomes. In their study they found interesting results. For example, they found that "the impact of health costs of government on reduction in mortality in children under 5 years is low and non-significant". Second, "in addition, the health costs didn't have a significant role in reducing child mortality, but 95 percent of the differences in mortality between countries is explained by these variables and other variables (per capita income, income distribution, mother's literacy rate and variables related to ethnic minorities).

\section{Methodology}

PLS or partial least squares approach as the second generation of structural equation modeling techniques has opened new horizons to behavioral scientists. With latent variable modeling approach, the result is obtained by calculating the measurement error on scales reducing the estimated relations, more accurate estimates of the interaction can be obtained. In PLS models two models are tested:

- Inner models

- Outer models

The outer model is similar to CFA and inner model is similar to path analysis in structural equation models. So after the test of the outer model, the inner model that reflects the relationship between latent variables of the study must be presented. The inner model can be used to test the hypothesis of the research's model.

SEM $=$ Confirmatory factor analysis + path analysis

Partial Least Squares Models = Inner model + outer model

In this method, it should be tried to find the set of factors for which the range of data is necessary. To do this, Figure 3 can be considered. In this figure, an axis in which the distribution data is at the highest is calculated, and when the sum of squared distances of all the points from that azis is minimum, that axis is called eigenvector. 


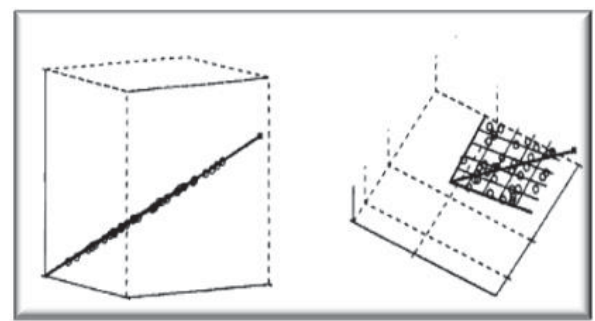

Figure 3: The first eigenvector or the factor related to the entire dataset

All spectra are then placed in an absorption matrix to calculate the first eigenvector. The eigenvector has maximum variance of the data whose eigenvector comprise all those points. This is why this eigenvector is still called the first principal component of data set. Figure 4 shows the curve of the first eigenvector of data sets.

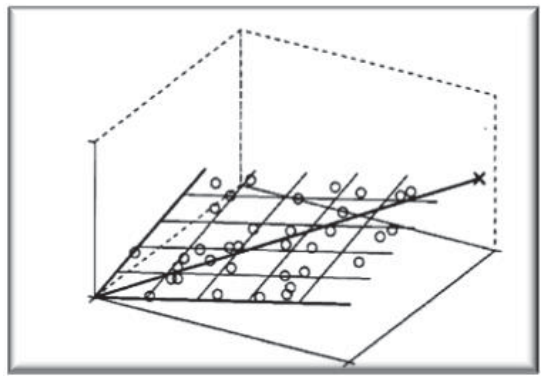

Figure 4: The curve of the first eigenvector of data set

Eigenvector must be in an area of data points to make the maximum variance of the data possible. Any movement, whether upwards or downwards the data level, of eigenvector will increase the squared sum of the distance of the points from the eigenvector. Now we should let the next vector to be determined in way that it would have the maximum residual variance not collected by the first vector; this is called second eigenvector. This vector must be perpendicular to the first eigenvector. If not, it may not ensure the maximum residual variance is the result of the first eigenvector (Figure 5).

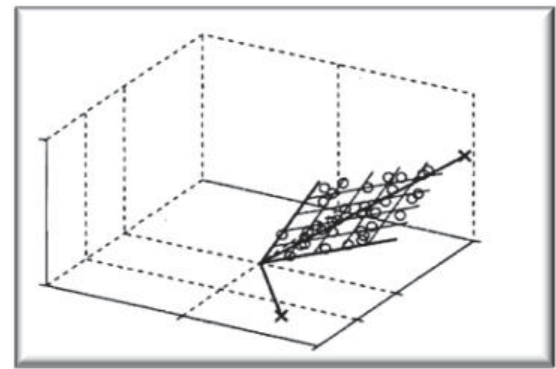

Figure 5: The curve of the first eigenvector and the second eigenvector of data set perpendicular to each other

By finding these pairs vectors that share the maximum variance, they can be used as the new coordinate. Based on the maximum variance of these two vectors, it can be ensured that but these two vectors, there is no other eigenvector that should be considered. Each vector here functions as a main factor or component of the data (These two vectors represent all of the data). Accordingly, the contribution of each explanatory variable effective on the dependent variable can be calculated. 


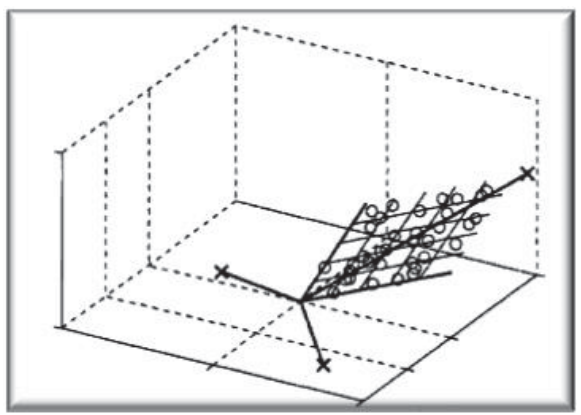

Figure 6: The third eigenvector perpendicular to the first and second eigenvector

\section{Model Estimation}

Before estimating the model, it is necessary to examine the distribution of health expenditures data in different income deciles. Based on the results of the estimation of the distribution function of health expenditure standardized data in the various deciles based on Monte Carlo method, it was seen that as we move from low deciles, the distribution of data shifts from normal to non-normal. In other words in lower income deciles, range of health expenditures fluctuations are more than high-income deciles. This can be due to the high proportion of health expenditure of total expenditure among lower income groups. This is consistent with evidence of the high level of low-income households' heavy expenses.

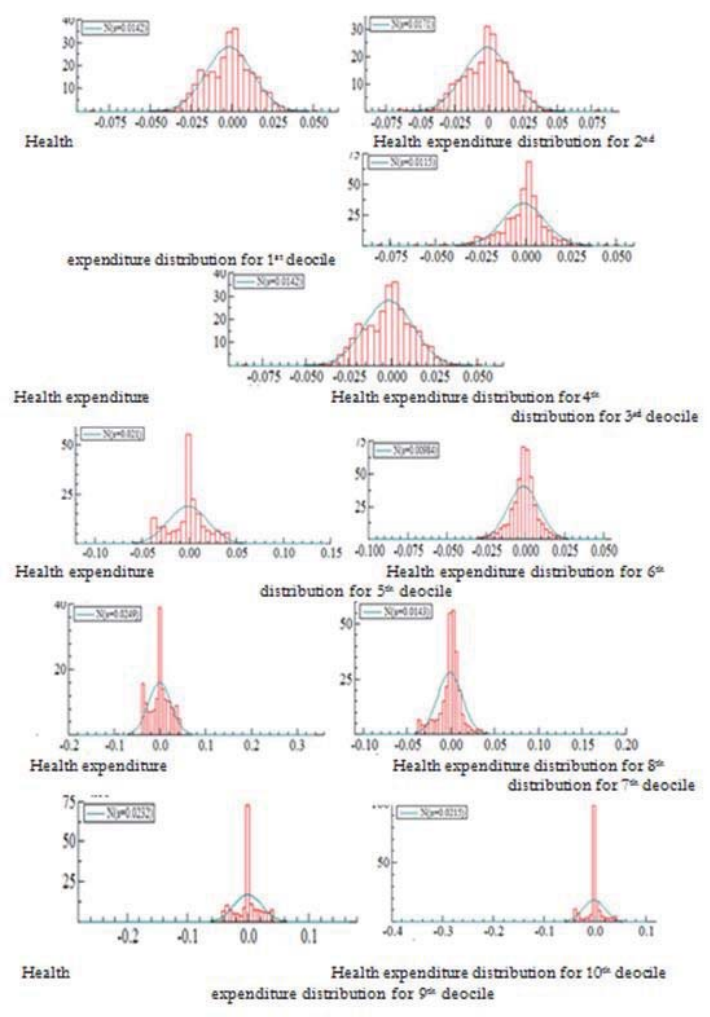

Figure 7: Distribution of health expenditure and income data 
Normal distribution of data of the research ensure that reliance on statistics $t$ and $F$ in determining the relationship between variables does not mislead the author. In the following, we introduce the main model and results from estimation of PLS model:

$$
y_{t}=f\left(X_{1}, X_{2}, \ldots . X_{11}\right)
$$

Where $Y$ represents the dependent variable and denotes health expenditures in different income deciles and explanatory variables $X$ indicates the factors affecting the level of healthcare spending. In this study, the effect of each of the 9 explanatory variables is as follows:

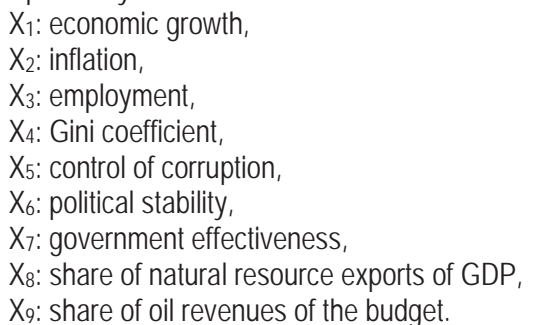

First the model is estimated with 7 components, it is seen from examining test statistics that from component 5 onwards, there is no increase in above statistics. $\mathrm{Q}^{2}$ calculation index shows quality of forecasts and overall estimate of the estimated models and its value is ideally equal to one; the Table (1) shows its reduction values from the fifth component onwards.

Table 1: Statistics of $\mathrm{Q}^{2}$ with different components

\begin{tabular}{ccc}
\hline Total & varshekastegi & Component \\
\hline 0.8737 & 0.8737 & Comp1 \\
0.3066 & 0.3066 & Comp2 \\
0.0514 & 0.0514 & Comp3 \\
0.0439 & 0.0439 & Comp4 \\
0.0585 & 0.0585 & Comp5 \\
-0.0038 & -0.0038 & Comp6 \\
\hline
\end{tabular}

Source: Author's calculations

Table 3 and Figure (8) show PLS model's quality depending on number of selected components. When $\mathrm{R}^{2}$ values of the dependent and independent variables $Y$ and $X$ and values of $Q^{2}$ are close to one, PLS model is better estimated:

Table 2: Statistics of study of efficiency of the model with different components

\begin{tabular}{cccccc}
\hline Comp5 & Comp4 & Comp3 & Comp2 & Comp1 & Index \\
\hline 0.9252 & 0.9206 & 0.9169 & 0.9124 & 0.8737 & $\mathrm{Q}^{2}$ cum \\
0.9712 & 0.9660 & 0.9604 & 0.9546 & 0.8724 & $\mathrm{R}^{2} \mathrm{Y}$ cum \\
0.5880 & 0.5104 & 0.4180 & 0.3093 & 0.1901 & $\mathrm{R}^{2}$ cum \\
\hline
\end{tabular}

Source: Author's calculations

Figure (8) shows correlation with the variable of health expenditures with two estimated components. Whenever vectors are closer to the center of circle above, the correlation between the explanatory variables and components will be less; as observed, correlation of health expenditures (blue dot) with components one and two is high. Besides, a number of independent variables of model that have a low correlation with the estimated components are placed near the center of the circle. 


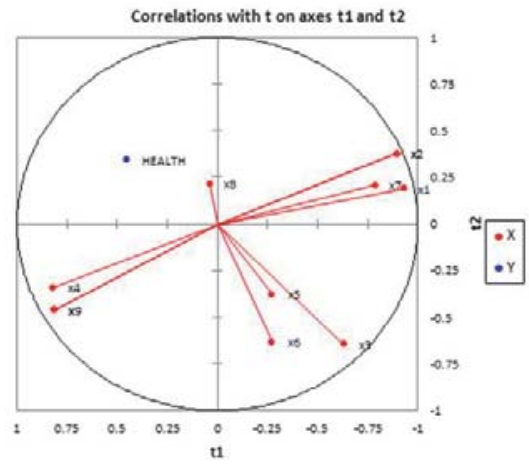

Figure 8: Correlation of model's variable with the estimated components Source: Author's calculations

In Table 4, variables are shown in order of importance in predicting that the index of health expenditures from top to bottom:

Table 4: Variables in order of importance for the first two components

\begin{tabular}{|c|c|c|c|c|c|c|c|c|}
\hline $\begin{array}{c}\text { Upper bound } \\
(95 \%)\end{array}$ & $\begin{array}{c}\text { Lower bound } \\
(95 \%)\end{array}$ & $\begin{array}{c}\text { Standard } \\
\text { deviation }\end{array}$ & VIP & $\begin{array}{c}\text { Upper bound } \\
(95 \%)\end{array}$ & $\begin{array}{c}\text { Lower bound } \\
(95 \%)\end{array}$ & $\begin{array}{c}\text { Standard } \\
\text { deviation }\end{array}$ & VIP & Variable \\
\hline 2.8088 & 0.8303 & 0.5047 & 1.8196 & 2.4302 & 1.2304 & 0.3061 & 1.8303 & $\mathrm{X} 2$ \\
\hline 1.7449 & 0.4875 & 0.3208 & 1.1162 & 1.9676 & 0.8352 & 0.2889 & 1.4014 & $\mathrm{X} 3$ \\
\hline 1.3377 & 0.5878 & 0.1913 & 0.9628 & 1.4171 & 0.4169 & 0.2552 & 0.9170 & $\mathrm{X} 1$ \\
\hline 1.2629 & 0.6140 & 0.1656 & 0.9384 & 1.5367 & 0.3294 & 0.3080 & 0.9330 & $\mathrm{X} 9$ \\
\hline 1.2629 & 0.6140 & 0.1656 & 0.9384 & 1.5367 & 0.3294 & 0.3080 & 0.9330 & $\mathrm{X} 4$ \\
\hline 0.9995 & 0.8068 & 0.0492 & 0.9031 & 1.9260 & -0.5040 & 0.6199 & 0.7110 & $\mathrm{X} 7$ \\
\hline 0.9995 & 0.8068 & 0.0492 & 0.9031 & 1.9260 & -0.5040 & 0.6199 & 0.7110 & $\mathrm{X} 6$ \\
\hline 1.3329 & 0.3859 & 0.2416 & 0.8594 & 1.1609 & 0.6973 & 0.1183 & 0.9291 & $\mathrm{X} 5$ \\
\hline 1.0952 & 0.5752 & 0.1327 & 0.8352 & 1.0370 & 0.5059 & 0.1355 & 0.7714 & $\mathrm{X} 8$ \\
\hline
\end{tabular}

Source: Author's calculations

According to results shown in Table 4, $x 2$ and $\times 3$ variables that respectively represent the indicators of inflation and employment make the highest contribution to the increase of health expenditures in different income classes.

Table (5) shows the correlation matrix of the explanatory variables of the model with each estimated component. As observed, correlation of healthcare expenses variable with the first component is relatively high and is the equal to 0.6545 .

Table 5: Correlation matrix of model variables with each of estimated components

\begin{tabular}{ccc}
\hline $\mathrm{t} 2$ & $\mathrm{t} 1$ & Variable \\
\hline 0.6430 & 0.6290 & $\mathrm{x} 2$ \\
-0.1888 & -0.9230 & $\mathrm{X3}$ \\
0.6336 & 0.2739 & $\mathrm{x} 1$ \\
0.3778 & 0.8914 & $\mathrm{x} 9$ \\
0.3778 & 0.8914 & $\mathrm{X} 4$ \\
-0.3398 & -0.8201 & $\mathrm{x} 7$ \\
-0.2120 & -0.7834 & $\mathrm{x} 6$ \\
-0.4618 & -0.8140 & $\mathrm{X5}$ \\
0.4618 & 0.8140 & $\mathrm{X8}$ \\
\hline 0.3456 & 0.6545 & $\mathrm{HEALTH}$ \\
\hline
\end{tabular}

Source: Author's calculations 
Table 6: Estimated impact of each estimated factor on different income classes

\begin{tabular}{|c|c|c|}
\hline $\mathrm{t} 2$ & $\mathrm{t} 1$ & Observation \\
\hline 1.8354 & -0.4546 & $\mathrm{y} 1$ \\
\hline 0.2839 & 0.1703 & $\mathrm{y} 2$ \\
\hline 0.4628 & 0.1166 & $\mathrm{y} 3$ \\
\hline 1.0379 & 0.4802 & $\mathrm{y} 4$ \\
\hline-1.2210 & -1.3111 & $\mathrm{y} 5$ \\
\hline-0.1123 & -0.5043 & $\mathrm{y} 6$ \\
\hline-0.4083 & 0.1317 & $\mathrm{y} 7$ \\
\hline 0.5170 & 0.8629 & $\mathrm{y} 8$ \\
\hline-0.0573 & 0.4061 & $\mathrm{y} 9$ \\
\hline 1.5153 & 0.4414 & $\mathrm{y} 10$ \\
\hline
\end{tabular}

Source: Author's calculations

According to Table 6, it is observed that economic and non-economic indices in the upper and lower deciles of income have a positive impact on health expenditures and in the middle deciles, they have a negative impact; however, according to the researcher, the positive nature of effects on the top and low deciles is different. In the lower deciles, increased spending is generally for health problems (essential goods), but in the top income deciles it is generally due to increased spending on health and beauty (luxury). Next, the effect of estimated indices on cost of healthcare will be discussed.

Table 7: Estimated coefficients of independent variables and their standard deviation

\begin{tabular}{|c|c|c|c|c|}
\hline Upper bound (95\%) & Lower bound (95\%) & Std. deviation & Coefficient & Variable \\
\hline-0.0437 & -0.6079 & 0.1439 & 0.3258 & $\mathrm{x} 2$ \\
\hline-0.0065 & -0.2670 & 0.0665 & -0.1368 & $\mathrm{X} 3$ \\
\hline-0.0727 & -0.2748 & 0.0516 & -0.1738 & $\mathrm{X} 1$ \\
\hline 0.1146 & -0.1553 & 0.0688 & 0.0204 & $\mathrm{X} 9$ \\
\hline 0.1146 & -0.1553 & 0.0688 & 0.0204 & $\mathrm{X} 4$ \\
\hline 0.0795 & -0.0045 & 0.0214 & 0.0375 & $\mathrm{X} 7$ \\
\hline 0.1715 & -0.1815 & 0.0901 & -0.0050 & $\mathrm{x} 6$ \\
\hline 0.0697 & -0.1075 & 0.0452 & 0.0189 & $\mathrm{X} 5$ \\
\hline 0.0697 & -0.1075 & 0.0452 & 0.0189 & $\mathrm{x} 8$ \\
\hline
\end{tabular}

Source: Author's calculations

According to the results in Table 7, it is seen that the variables of employment, economic growth and political stability have a negative impact on health expenditures in different income classes and other indicators have positive impact on health care spending in different income classes. Accordingly, we can say that the impact of good governance and resource curse factors on healthcare index is negative.

\section{Conclusion}

\section{??????????????????}

\section{References}

Assari, A.; Rasouli, A. 2015. Examining the effect of economic, social, political, cultural factors and health level in different income classes (using PLS). The International Conference on Economics. Journal of Health Economics

Sabbagh Kermani, M.; Baskha M., 2008. The role of good governance in improving the functioning of government spending: a case study of the health and education sectors in Islamic countries

Alesina, A., Deveelschauwer, A., Easterly, W. Kurlat, S., Wacziarg, R. 2003. Fractionalization . Journal of Economic Growth 8(2): 155194. 
Alexeev, M., Conrad, R. 2004 The elusive curse of oil. The Review of Economics and Statistics 91(3): 586-598.

Auty, R.M. 2001. Resource abundance and economic development. Oxford: Oxford University Press.

Barro, R.J. 2000. Education and economic growth. In OECD (Organization for Economic Cooperation and Development) Symposium on the contribution of human and social capital to sustainable economic growth and well-being. Québec City , Canada, 19-21 March 2000 .

Bhargava, A., Jamison, D.T., Lau, L.J., Murray, C.J.L. 2001. Modeling the effects of health on economic growth. Journal of Health Economics 20(3): 423-440.

Bhattacharyya, S., Hodler, R. 2010 Natural resources, democracy and corruption.European Economic Review 54(4): 608-621.

Bjørnskov, C. 2010. Do Elites Benefit from Democracy and Foreign Aid in Developing Countries?. Journal of Development Economics 92 (2): 115-124.

Boschini, A.D., Pettersson, J., Roine, J. 2007. Resource curse or not : A question of appropriability. The Scandinavian Journal of Economics 109(3): 593-617.

Brunnschweiler, C.N., Bulte, E.H. 2008. The resource curse revisited and revised:a tale of paradoxes and red herrings. Journal of Environmental Economics and Management 55(3): 248-264.

Brunnschweiler, C.N., Bulte, E.H. 2009. Natural resources and violent conflict: Resource abundance, dependence and the onset of civil war. Oxford Economic Papers 61(4):651-674.

Bulte, E., Damania, R., Deacon, R. 2005. Resource intensity, institutions, and development. World Development 33(7):1029-1044.

Carmignani, F., Avom, D. 2010. The social development effects of primary commodity export dependence", Ecological Economics 70(2):317-330.

Carmignani, F. 2013. Development outcomes, resource abundance, and the transmission through inequality. Resource and Energy Economics 35(3): 412-428.

Clemente, J., Marcuello, C., Montañés, A., Pueyo, F. 2004. On the international stability of health care expenditure functions: are government and private functions similar?. Journal of Health Economics 23(3): 589-613.

Collier, P., Goderis, B. 2007. Commodity prices, growth, and the natural resource curse: reconciling a conundrum. Centre for the Study of African Economies Working Paper No.274: Oxford.

Collier, P., Hoeffler, A. 2003. Aid, Policy, and Peace: reducing the risks of civil conflict. Defense and Peace Economics 13 (6): $435-450$.

Costa-Font, J., Gemmill, M., Rubert, G. 2011.Biases in the healthcare luxury good hypothesis?: a meta-regression analysis. Journal of the Royal Statistical Society 147(1): 95-107.

Cotet, A.M., Tsui, K.K. 2013. Oil and Conflict: What Does the Cross Country Evidence Really Show?. American Economic Journal 5(1): 49-80.

Centre for Systemic Peace 2013. Polity IV Project : Political regime characteristics and transitions, 1800-2012. Available at $24 \cdot 10 B$ working Paper 2014-01 Natural resources and public spending on health <http://www.systemicpeace.org/polity/polity4.htm> (Accessed 31 October 2013).

Daniele, V. 2011. Natural resources and the 'quality' of development. Journal of Development Studies 47(4): 545-573.

Davis, G.A. 2013. Replicating Sachs and Warner's working papers on the resource curse. Journal of Development Studies 49(12):16151630.

Delavallade, C. 2006. Corruption anddistribution of public spending in developing countries. Journal of Economics and Finance 30(2): 222-239.

Desmet, K., Ortin, I., Wacziarg, R. 2012. The political economy of linguistic cleavages. Journal of Development Economics 97(2): 322338.

Mehlum, J., Moene, K., Torvik, R. 2006. Institutions and the resource curse. The Economic Journal 116(508): 1-20.

Gylfason, T. 2009. Development and growth in mineral-rich countries. In R. Bleischwitz,, P.J.J. Welfens, Z.X. Zhang, eds 2009. Sustainable Growth and Resource Productivity: Economic and Global Policy Issues, Austin: Greenleaf Publishing : 42-8

Virmani, A., Sahu, S. and Tanwar, S. (2006), Governance In the Provision Of Public Goods In South Asia, Indian Council for Research on linternational Economic Relation, SANEI, Project no. 4. New Delhi.

Lazarova, E., and I., Mosca (2007), Does Governance Matter for Aggregate Health Capital? Applied Economics Letters, 15: $199-202$.

Kaufman, D., Kraay, A., Mastruzzi, M. (2004), Governance matters III: governance indicators for 1996, 1998, 2000, and 2002, World Bank Economic Review, 18: 253-287.

Kaufmann, D., A. Kraay and M. Mastruzzi (2007), Governance Matters VI: Aggregate and Individual Governance Indicators $1996-2006$. Washington:World Bank.

Kaufmann, D., Kraay, A., Zoido-Lobaton, P. (1999), Governance matters,Development Economics Research Group, Washington, DC: World Bank.

Kaufmann, D. and Kraay A. (2007), Governance Indicators: Where Are We,Where Should We Be Going? Global governance Group, Policy ResearchWorking Papers, No 4370, Washington DC: World Bank.

Filmer, D., Hammer, J., Pritchett, L. (2000), Weak links in the chain: a diagnosis of health policy in poor countries, The World Bank Research Observer, 15: 199-224. 